$\begin{array}{r}\text { Phinisi Integration Review } \\ \text { Vol. 1, No.2, Agustus 2018 Hal 259-271 } \\ \text { Website: } \text { http://ojs.unm.ac.id/pir } \\ \hline\end{array}$

\title{
Implementasi Pola Sosialisasi Represipatif Di Pesantren Immim Putra Makassar Dalam Pembentukan Karakter Santri Yang Unggul
}

\author{
Mursyid \\ Pendidikan Sosiologi, Program Pascasarjana, Universitas Negeri Makassar \\ Email: mursyidpolewali65@gmail.com
}

\begin{abstract}
Abstrak. Tujuan penelitian adalah untuk mengetahui bagaimana pola represipatif diterapkan, bagaimana santri menyikapi pola sosialisasi represipatif dalam proses sosialisasi, dan bagaimana dampak yang ditimbulkan dengan penerapan pola sosialisasi represipatif dalam proses pembinaan santri, khususnya di pesantren IMMIM Putra Makassar. Jenis penelitian kualitatif fenomenologi menggunakan analisis deskriptif kualitatif yaitu penelitian yang dilakukan untuk memperoleh gambaran situasi dan kejadian-kejadian atau berbagai fenomena secara kongkrit tentang objek atau masalah penelitian. Metode pengumpulan data dilakukan melalui Library research, Field research (observasi, wawancara, dan dokumentasi). Analisis data dilakukan dengan cara reduksi data, penyajian data dan kesimpulan/verifikasi data. Pola sosialisasi ini menggabungkan antara pola sosialisasi represif dengan partisipatif secara bersinergis dalam suatu proses sosialisasi. Hasil menunjukkan bahwa cara penerapan pola sosialisasi represipatif ini mengutamakan pada menumbuhkan pemahaman santri terhadap tujuan dan makna-makna dari setiap peraturan yang ditetapkan, melalui keterlibatan santri, dengan mekanisme tertentu dan memaksimalkan pungsi-pungsi struktur sebagai tim yang harus bekerja sama. Dengan pemahaman santri tersebut mendorong munculnya sikap positif santri terhadap pola represipatif ini, yang ditandai dengan sikap proakttif santri dalam proses pembinaan. Dampaknya adalah terbangunnya kerja sama antara pihak pembina dengan santri dalam proses pembinaan, tumbuhnya perasaan nyaman bagi santri dalam pondok, yang kemudian mendorong tumbuhnya rasa percaya diri, kreatifitas, dan menunjukkan kebiasaankebiasaan bertindak dengan karakter-karakter unggul dikalangan santri yaitu karakter yang senantiasa dilandasi oleh nilai-nilai islami, bukan karakter yang hanya berdasarkan pada perenungan tentang apa yang baik dan apa yang buruk belaka.
\end{abstract}

Kata kunci: Pola sosialisasi represipatif, Karakter unggul, Santri

\begin{abstract}
The purpose of his study is to find out how the pattern of repressivatife applied, how the students respond to the pattern of repressivatife socialization during socializing process, and how the impact caused by the implementation of repressivatife socialization pattern in the process of guiding the students, especially at Pesantren IMMIM Putra Makassar. This is a qualitative research of phenomenology by using qualitative descriptive analysis, a research which is done by getting the illustration of a situation and events or various phenomenon concretely about research object or research problem. Methods in collecting data are done trough library research, field research (observation, interview, and documentation). Data analysis is done by data reduction, data presentation and coclusion or data verification. Repessivatife socialization is a pattern of socialization that combines the pattern with repressive socialization and particivatife socialization in a synergistic socialization process. The results of this study indicate that the way of applying the pattern emphasized on cultivating students understanding of the goals and meanings in each established rule, through the students involvement, whit certain mechanisms and maximizing the structural fungtions as a cooperated team. By having a clear understanding of the pattern, the student can ancourage their positive attitude towards this reprssivatife pattern, wich is marked by the proactive attitude during guiding process. The impact is the establishment of cooperatin between the
\end{abstract}


guider and the students during the process, the growing sense of comfort for students in the cottage, wich then encourages the growth of confidence, creativity, and also showing the habitual acts of superior characters among student at muslim school.

Keywords: Repressivatife socialization patten, superior character, students.

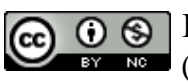
Ini adalah artikel dengan akses terbuka dibawah licenci CC BY-NC-4.0 (https://creativecommons.org/licenses/by-nc/4.0/ )

\section{PENDAHULUAN}

Pendidikan merupakan salah satu jalan yang utama dan sangat strategis dalam upaya menciptakan dan mengembangkan kualitas sumber daya manusia (SDM) yang unggul. Salah satu fungsi lembaga pendidikan atau sekolah adalah selain memberikan dan menanamkan bekal ilmu pengetahuan secara kognitif juga untuk menanamkan sikap kepribadian yang baik terhadap peserta didik.

Didalam Undang Undang Republik Indonesia Nomor 20 Tahun 2003 Tentang Sisdiknas sebagai rujukan dalam pengelolaan pendidikan, dikatakan bahwa: " Pendidikan nasional berfungsi mengembangkan kemampuan dan membentuk watak serta peradaban bangsa yang bermartabat dalam rangka mencerdaskan kehidupan bangsa, bertujuan untuk berkembangnya potensi peserta didik agar menjadi manusia beriman dan bertaqwa kepada Tuhan Yang Maha Esa, berakhlak mulia,berilmu,cakap,kreatif,mandiri, dan menjadi warga negara yang demokratis serta bertanggung jawab". (UU Sisdiknas No. 20 tahun 2003)

Berangkat dari UU Sisdiknas sebagaimana diuraikan diatas, dapatlah disadari bahwa lembaga pendidikan sekolah, memiliki beban yang cukup berat untuk mempersiapkan peserta didik menjadi generasi-generasi unggul yang berdaya saing tinggi baik dari segi keilmuan secara kognitif maupun terutama dari segi karakter kepribadian.

S.Nasution (2009) sebagaimana dikutip oleh Abdullah Idi, (2016:61) mengatakan bahwa pada dasarnya setiap sekolah berusaha untuk mendidik siswa agar mampu menjadi anggota masyarakat yang berguna, meskipun apa yang diajarkan disekolah seringkali banyak yang berbeda atau kurang relevan dengan kehidupan nyata dalam masyarakat.

Kemajuan suatu bangsa juga sangat banyak ditentukan oleh sejauh mana sektor pendidikan mendapat perhatian serius dari seluruh komponen yang terlibat dalam pengelolaan atau pelaksanaan pendidikan, mulai dari pemerintah, keluarga, dan bahkan masyarakat secara umum.

Pemerintah telah melakukan berbagai upaya perbaikan untuk menciptakan dunia pendidikan yang lebih ideal, misalnya renovasi atau perbaikan kurikulum untuk disesuaikan dengan kebutuhan zaman. Namun kenyataan yang ada menunjukkan bahwa masih terdapat peserta didik atau siswa dari berbagai sekolah yang kurang mampu menunjukkan karakter kepribadian yang ideal sebagaimana yang diharapkan, bahkan yang terjadi adalah masih terdapat banyak siswa yang dapat dikategorikan berperilaku kurang etis ditengah-tengah masyarakat.

Kondisi ini tentu saja sangat memperihatinkan oleh semua pihak yang berkepentingan didalamnya. Lalu pertanyaan yang muncul kemudian, adalah apa yang salah dalam dunia pendidikan, pertanyaan ini menarik untuk dicermati oleh karena penyikapan terhadap dunia pendidikan terpulang pada tiga komponen dasar yang bertanggung jawab yaitu pemerintah, masyarakat dan keluarga yang dikenal dengan pendidikan formal, nonformal dan informal. Tiga komponen ini sangat diharapkan untuk selalu bersinergis dalam menyikapi berbagai permasalahan pendidikan.

Berangkat dari keprihatinan tersebut maka analisis dalam penelitian ini lebih banyak diorientasikan pada kajian bagaimana pola sosialisasi yang tepat sebagai suatu strategi untuk menanamkan nilai-nilai kebaikan dalam upaya pembentukan karakter kepribadian siswa di sekolah. Secara garis besar ada dua pola utama dalam proses sosialisasi terhadap anak atau siswa, dimana dua pola tersebut cenderung memiliki asumsi dasar yang berbeda, yaitu pola sosialisasi represif lebih berkecenderungan pada penekanan kepatuhan siswa terhadap setiap peraturan secara sepihak, dan pola sosialisasi 
partisipatif yang lebih berkencenderungan pada pemberian kebebasan kepada siswa untuk mementukan keinginannya sendiri dimana para guru hanya berfungsi sebagai pemberi saran dan masukan saja.

Penelitian terkait pola sosialisasi dalam pembentukan karakter ini telah banyak dilakukan oleh peneliti sebelumnya, Salah satu diantaranya adalah penelitian tentang fungsi sosialisasi represif terhadap perilaku disiplin siswa yang menyimpulkan bahwa penerapan pola sosialisasi refresif mempengaruhi peningkatan kedisiplinan siswa. Pengaruh tersebut ditandai dengan berkurangnya tingkat pelanggaran terhadap tata tertib yang ditetapkan oleh sekolah,tetapi kedisiplinan tersebut tidak didasari oleh kesadaran siswa melainkan karena rasa takut terhadap sanksi yang diterapkan. (internet: untan.ac.id. 2014: )

Penelitian sama yang lain adalah penelitian tentang "makna sosialisasi nilai orang tua terhadap anak tunggal" yang menyimpulkan bahwa para orang tua yang menjadi objek penelitian, menggunakan pola sosialisasi yang berbeda-beda, dan menunjukkan adanya perbedaan tingkah laku anak berdasarkan pola sosialisasi yang digunakan oleh orang tua masing-masing. (Internet: unair.ac.id. 2014)

Mencermati penelitian yang diuraikan diatas, dapat disimpulkan bahwa sangat jarang yang menggunakan pola penggabungan antara pola represif dengan partisipatif dalam proses sosialisasi. Oleh karena itu pada penelitian ini, peneliti akan mengungkap sejauh mana epektifitas pembinaan jika sosialisasi yang dilakukan menggabungkan antara pola sosialisasi represif dengan pola sosialisasi partisipatif yang dalam penelitian ini diistilahkan dengan pola represipatif. Landasan teori pendukung dalam penelitian ini, yang pertama adalah teori keseimbangan (Balance Theory) oleh Fritz Heider. Teori ini digunakan karena sangat relevan dengan focus penelitian dimana asumsi dasar teori ini mengedepankan perlunya harmonisasi hubungan antar unsureunsur utama dalam interaksi yaitu unsure individu (I), orang lain $(\mathrm{O}$, dan unsure objek sikap (OB). Hubungan antar unsure-unsur tersebut memegang peranan penting dalam menentukan keseimbangan atau ketidak seimbangan.(Internet:rikafatmawati.blogpost.c o.id, 2015) Kedua adalah teori konsistensi afektif-kognitif oleh Rosenberg. Asumsi dasar dari teori ini juga sangat besesuaian dengan focus penelitian ini oleh karena dalam teori ini berasumsi dasar bahwa didalam memahami suatu fakta seseorang selalu berussaha untuk membuat kesesuaian antara afeksi (perasaan) dan kognisinya (pengetahuan). Oleh sebab itu peran afeksi dan kognisi sangat besar pengaruhnya dalam perubahan sikap dan karakter. (Internet: digilib.unismus.oc.id, 2015)

Penelitian ini dilakukan dilembaga pendidikan berbasis pesantren, tepatnya di pesantren IMMIM putra Makassar dengan pertimbangan bahwa, lembaga pendidikan yang berbasis pesantren, memiliki keunikan tersendiri yang berbeda dengan lembagalembaga pendidikan umum. Perbedaanperbedaan tersebut dapat dilihat dalam berbagai keadaan, misalnya Santri berasal dari berbagai daerah yang berbeda-beda, dengan tradisi dan kebiasaan-kebiasaan yang berbeda pula, kemudian diasramakan dan dipersatukan dalam kehidupan pondok dengan tata aturan yang mengikat santri dan segala macam dinamikanya. Implikasinya adalah sangat berpotensi timbulnya berbagai macam masalah, terutama dalam penegakan kedisiplinan, dengan demikian sangat diperlukan adanya tata kelola pondok sebagai norma yang menjadi rujukan dalam pengelolaan. Pada tiga tahun terakhir ini di Pesantren IMMIM telah melakukan proses sosialisasi represipatif yang menggabungkan antara pola sosialisasi represif dengan pola partisipatif, yang kemudian akan dijadikan acuan dalam penelitian ini.

\section{METODE PENELITIAN}

Penelitian ini adalah penelitian kualitatif fenomenologi dengan menggunakan analisis deskriptif yaitu penelitian yang dilakukan untuk memperoleh gambaran situasi atau berbagai fenomena secara kongkrit tentang objek atau masalah penelitian. Bogdan dan Taylor dalam Moleong (2007:4-6) mendefinisikan metodologi kualitatif sebagai prosedur penelitian yang menghasilkan data deskriptif berupa kata-kata tertulis atau lisan dari orang-orang dan perilaku yang dapat diamati. Untuk mendapatkan berbagai informasi dan keterangan-keterangan yang dibutuhkan, ditentukan informan melalui dua cara yaitu purposive sampling adalah menentukan nara sumber berdasarkan pertimbangan tertentu, misalnya orang tersebut dianggap paling mengetahui hal-hal yang diinginkan dalam 
penelitian. Sedangkan Snowball sampling adalah pertimbangan jumlah nara sumber yang akan dipergunakan dalam penelitian, misalnya dari jumlah yang sedikit menjadi banyak berdasarkan pertimbangan kebutuhan untuk menjawab permasalahan penelitian.

Teknik pengumpulan data yang dipergunakan sebagai berikut:

1. Library research, yaitu peneliti melakukan riset kepustakaan, dengan membaca berbagai referensi yang relevan untuk dipergunakan sebagai salah satu dasar pertimbangan dalam mengambil kesimpulan.

2. Field research, yaitu peneliti melakukan riset melalui pengamatan dan observasi langsung kelokasi penelitian. Teknik ini dilakukan dengan cara utama sebagai berikut:

a. Tahap pertama adalah melakukan observasi/pengamatan. Tekhnik yang digunakan adalah pengamatan partisipan yaitu peneliti ikut serta dalam berbagai aktifitas yang dilakukan di dalam pondok pesantren IMMIM sambil mengamati, memperhatikan dan mencatat secara seksama dan mendalam berbagai fenomena yang terjadi dalam proses kehidupan sehari-hari di dalam pondok pesantren IMMIM, seperti perilaku santri,perilaku para pembina dan guru-guru, termasuk bagaimana penegakan kedisiplinan dan lain-lain yang terkait dalam pengelolaan pondok, kemudian hasil pengamatan tersebut dideskrifsikan dalam bentuk suatu uraian konsep yang dapat dipahami dan dimaknai.

b. Tahap kedua adalah melakukan wawancara (Interview), yaitu mengumpulkan data-data dan informasi yang dibutuhkan dengan cara peneliti melakukan tanya jawab dengan pihakpihak atau orang-orang (informan) yang dianggap kompeten untuk dimintai pendapat, ide-ide dan berbagai informasi yang dibutuhkan. Dalam wawancara ini peneliti mendengarkan penjelasan informan dan mencatat dengan teliti dan seksama, sambil memperjelas pernyataan-pernyataan informan yang dianggap masih samarsamar, kemudian hasil wawancara ini dideskrifsikan menjadi jawabanjawaban masalah dalam penelitian. c. Tahap ketiga, adalah dokumentasi, yaitu mengumpulkan data-data melalui pencarian dokumen-dokumen yang dibutuhkan, terutama seperti dokumendokumen tata tertib pondok, konsep tata kelola pondok dan lain-lain yang dibutuhkan, disamping itu dilakukan pengambilan gambar atau foto untuk memperkuat data observasi maupun wawancara.

Dalam penelitian kualitatif umumnya datadata diperoleh dari berbagai sumber sehingga sangat memungkinkan terdapatnya data-data yang beragam dan variatif. sehingga seringkali menyulitkan peneliti untuk merumuskan menjadi kesimpulan. Disamping itu menurut Miles dan Huberman sebagaimana dikutif oleh Sugiyono (2016:334) menguatkan pernyataan diatas bahwa yang paling serius dan sulit dalam analisis data kualitatif adalah karena, metode analisis belum dirumuskan dengan baik. demikian juga Stainback dalam kutipan yang sama oleh Sugiyono (2016:334) menyatakan bahwa belum ada panduan dalam penelitian kualitatif untuk menentukan berapa banyak data dan analisis yang diperlukan untuk mendukung kesimpulan atau teori.

Analisis data yang dipergunakan dalam penelitian ini merujuk pada model Miles dan Huberman sebagaimana yang dikutip Sugiyono (2016:337). yaitu (1). Pengumpulan data, (2). Reduksi data, (3). Penyajian data, (4).Kesimpulan/Verifikasi.

Sedangkan uji keabsahan data menekankan pada aspek validitas data yaitu adanya kesesuaian antara data yang dilaporkan peneliti dengan data yang sesungguhnya terjadi pada objek penelitian.

Menurut Sugiyono, uji keabsahan data pada penelitian kualitatif dapat dilakukan dengan empat cara yaitu, uji kredibilitas data, uji transferability, uji dependability, dan uji confirmality. (2016 366). Dari keempat langkah uji keabsahan data tersebut yang akan dipergunakan dalam penelitian ini adalah uji kredibilitas data (keterpercayaan data)

Uji Kredibilitas data dimaksudkan agar data dan informasi yang telah dikumpulkan harus mengandung nilai kebenaran yang dapat dipercaya, bukan sebagai suatu data yang direkayasa. Untuk mengetahui kredibilitas data dalam penelitian ini, akan menggunakan cara perpanjangan pengamatan, peningkatan ketekunan, triangulasi, menggunakan bahan referensi. 


\section{HASIL DAN PEMBAHASAN}

Pola sosialisasi represif (Repressive Sociallization) lebih berkecenderungan pada adanya penekanan kepatuhan santri terhadap berbagai peraturan, tatanan, system yang telah ditentukan secara sepihak oleh para guru, pembina atau pengelola pondok, komunikasi dalam pola ini sifatnya satu arah dari para guru, pembina atau pengelola pondok, akibatnya sangat potensial munculnya rasa tertekan, rasa tidak suka, kurang pecaya diri, bahkan rasa dendam dari santri sebagai objek dalam pembinaan. Sedangkan pola sosialisasi partisipatif (Particivatife Sociallization) lebih berkecenderungan pada adanya pemberian kebebasan atau otonomi kepada santri dalam menentukan keinginannya, dimana para pembina, guru hanya berperan sebagai pemberi saran, ataupun motivasi terhadap keinginan santri, komunikasi yang terjadi cenderung dikendalikan oleh santri, sehingga sangat berpotensi munculnya rasa arogansi santri karena perasaan mandiri yang berlebihan. Hal ini menunjukkan adanya kecenderungan yang kurang epektif jika pola sosialisasi yang dilakukan hanya menggunakan salah satu dari dua pola sosialisasi yaitu sosialisasi represif atau pola sosialisasi partisipatif.

Membandingkan hasil penelitian yang dilakukan di Pesantren IMMIM Putra Makassar, menunjukkan bahwa lebih efektif pengaruh dan dampak penerapan pola sosialisasi represipatif (Repressivatife Socialization). yang memadukan secara sinergitas kedua pola sosialisasi (represif dan partisipatif) dalam proses sosialisasi. karena dengan perpaduan tersebut mendorong terbentuknya karakter dan mental santri yang seimbang antara sikap disiplin yang kuat dengan kebebasan. sehingga menjadi motivasi bagi santri untuk membangun kemandirian dalam bingkai ketaatan pada berbagai norma-norma yang berlaku.

Berikut ini akan dibahas cara penerapan, tanggapan santri, dan dampak penerapan pola sosialisasi represipatif dikaitkan dengan beberapa teori pendukung.

\section{Penerapan Pola Sosialisasi Represipatif}

a) Pemberdayaan fungsi pengelola secara struktural.

Pemberdayaan fungsi struktural yang dimaksudkan adalah memperkuat fungsi-fungsi menegemen yaitu kerja sama diantara para pengelola pondok baik secara vertikal maupun horizontal berdasarkan posisi dalam struktur.
Hal ini penting oleh karena penerapan pola sosialisasi represipatif harus dilakukan secara berkesinambungan dan bersinergis antara satu bidang pengelola dengan bidang pengelola lainnya yang ada dalam pondok, sehingga sangat dibutuhkan untuk memaksimalkan fungsi dan peran strategis para pengelola, terutama dalam kaitan penerapan suatu pola sosialisasi dalam proses pembinaan. Terbangunnya kerjasama, cara pandang dan pendekatan yang bersinergis antara pengelola menjadi factor penentu berjalannya proses pembinaan secara maksimal.

b) Membangun kemampuan adaptasi diri.

Adaptasi yang dimaksudkan adalah kemampuan yang dimiliki untuk dapat menyesuaikan diri dengan berbagai tuntutan dan kewajiban yang harus dijalankan dalam proses pembinaan. Melalui kemampuan adaptasi ini, akan menjadi motivasi untuk senantiasa berupaya menyesuaikan diri dengan berbagai kondisi, atau situasi pondok dengan berbagai macam nilai dan norma-normanya. Dalam menciptakan kemampuan adaptasi di pesantren IMMIM diperlukan terbangunnya pemahaman yang sinergis antara pengelola dengan santri melalui upaya sebagai berikut:

(1) Pemahaman Pengelola:

Memberikan pemahaman secara mendalam tentang asumsi dasar pola sosialisasi represipatif kepada para pembina (Wali Thalib), para Guru, bahkan kepada seluruh yang terlibat dalam pengelolaan pondok. Hal ini sangat penting karena jika konsepnya tidak dipahami dengan baik, maka prosesnya sangat memungkinkan tidak berjalan maksimal.

(2) Pemahaman Santri

Pola sosialisasi represipatif juga dipahamkan secara mendalam kepada para santri sebagai objek binaan, dimaksudkan agar terbangun persepsi yang sama antara para pembina (Wali Thalib), guru, dengan para santri. Selain itu, juga santri diberikan pemahaman yang mendalam terkait maksud dan tujuan program pembinaan yang dilakukan dengan berbagai norma-norma sebagai aturan, dengan pemahaman tersebut akan mendorong keinginan santri untuk beradaptasi dengan berbagai norma-norma dan nilai-nilai pondok.

Abdullah Idi (2016:102-103) menjelaskan bahwa proses penyesuaian diri dapat dipandang dari dua perspektif, yaitu perspektif kualitas atau efisiensinya dan perspektif proses berlangsungnya. Pada perspektif kualitas atau efisiensinya berarti berhasil tidaknya 
penyesuaian diri dilihat pada empat aspek utama yaitu: (1) kepuasan psikis, (2) efisiensi kerja / aktivitas, (3) gejala fisik, (4) penerimaan social. Sedangkan pada perspektif proses berlangsungnya, berarti penyesuaian diri merupakan proses progressif yang mendorong individu untuk dapat menguasai, mengubah, atau menahan impuls-impuls dalam dirinya, dan disesuaikan dengan tuntutan atau kondisikondisi lingkungannya.

Kemampuan adaptasi dan penyesuaian diri, dengan sendirinya akan mengarah pada kemampuan santri untuk merubah sikap dan perilaku yang seimbang antara apa yang diinginkan dengan apa yang diharuskan. Keseimbangan antara keinginan dan tuntutan tersebut menjadi modal kuat dalam upaya merubah karakter dan kepribadian santri menjadi karakter yang unggul.

\section{c). Mekanisme pola implementasi.}

(1) Keterlibatan Santri.

Dalam batas-batas tertentu Santri dilibatkan untuk memberikan pertimbangan dan pendapat dalam penetapan berbagai kebijakan, khususnya yang terkait norma-norma atau peraturan-peraturan pembinaan dan sanksi-sanki yang ditimbulkan sebagai akibat pelanggaran terhadap norma pondok. Tujuannya adalah untuk membangun kesepakatan terhadap acuan dalam proses pembinaan .

(2) Komunikasi Terarah :

Metode komunikasi pembina, guru dan semua pengelola pondok kepada santri adalah sistim komunikasi terarah, yaitu sistim komunikasi yang mengedepankan terbangunnya tujuan yang sama terhadap apa yang sudah menjadi kesepakatan, tujuannya adalah agar interaksi dalam proses pembinaan selalu menuju pada keserasian dan keseimbangan antara pembina, guru dan para pengelola dengan santri.

(3) Imbalan dan Sanksi:

Memberikan penghargaan sekecil apapun suatu prestasi atau perbuatan bernilai baik yang dilakukan oleh santri, dalam bentuk material berupa hadiah maupun dalam bentuk immaterial berupa pujian atau selembar keterangan kebaikan. Demikian juga sebaliknya memberikan hukuman terhadap perilaku keliru yang seimbang, baik dalam bentuk hukuman fisik sesuai standar hukuman yang telah disepakati, maupun hukuman dalam bentuk simbolik seperti menghapal kosa kata bahasa asing, maupun dalam bentuk nasihat.

(4) Proses Sosialisasi Seimbang:
Proses sosialisasi berjalan seiring antara pihak pengelola pondok, Guru, Wali Thalib dengan santri. Tidak semua pengendalian datangnya dari pengelola pondok secara diktator, tidak juga dibenarkan otonomi santri, tetapi sosialisasi senantiasa diarahkan kepada bagaimana santri dapat memahami maknamakna dari setiap peraturan sebagai norma pondok yang harus dijalankan secara bersama, dibawa kendali para pembina pondok. Keseimbangan antara keinginan dan tuntutan lingkungan sosial sebagaimana diuraikan diatas, sangat bersesuaian atau didukung oleh teori keseimbangan ( Balance Theory). yaitu salah satu teori yang dikembangkan oleh Fritz Heider. Teori ini berasumsi bahwa perubahan sikap positif dapat dilakukan dengan menciptakan kesamaan persepsi antara unsur utama yaitu individu (I), orang lain (O), dan objek sikap (OB). Hubungan antara unsur utama tersebut memegang peranan penting dalam menentukan keseimbangan atau ketidak seimbangan dalam menjalani suatu proses interaksi sosial dalam suatu kehidupan kelompok sosial. (Internet: 2015, rikafatmawati.blogpost.co.id)

(5) Pembatasan Keperluan Santri sesuai Kebutuhan:

Pembatasan keperluan yang dimaksudkan adalah, tidak semua fasilitas diperbolehkan dimiliki oleh santri secara pribadi, tetapi fasilitas yang memang menjadi kebutuhan dasar dan penting yang harus ada untuk memperlancar proses pembinaan, disiapkan oleh pondok dengan penggunaan yang tertata. Misalnya, Santri tidak dibenarkan untuk membawa dan memiliki HP secara pribadi di dalam pondok, tetapi disiapkan sarana berkomunikasi bagi santri.

(6) Pantauan Sikap:

Dalam memantau perkembangan sikap santri, sistim yang dilakuan adalah sistim kredit poin, kredit poin adalah memberikan poin kebaikan kepada setiap santri setiap awal bulan sejumlah seratus (100) sebagai modal untuk memenuhi target kebaikan sikap dalam satu bulan. Modal tersebut bisa bertambah dan juga sebaliknya bisa berkurang tergantung tindakan kebaikan atau tindakan pelanggaran yang dilakukan oleh santri. Kredit poin tersebut dikontrol di kelas, di asrama, di ruang makan, di mesjid, dan diberbagai tempat, dengan menggunakan sejumlah indicator poin pelanggaran. Setiap santri yang melakukan pelanggaran maka point kebaikannya berkurang, 
demikian juga setiap santri melakukuan kebaikan maka poinnya akan bertambah. Setiap akhir bulan, poin kebaikan tersebut di kumpulkan untuk diperiksa dan dianalisis. Santri yang mampu mempertahankan modal kebaikannya, atau bahkan menamba jumlah modal maka akan diberi penghargaan, sedangkan yang tidak mampu mempertahankan bahkan minus akan diberi arahan dan nasehat.

(7) Memperkuat Komunikasi Dengan Orang Tua/Wali Santri

Dalam menerapkan suatu kebijakan terhadap santri, sangat diperlukan adanya dukungan maksimal dari pihak orang tua, sebab dengan dukungan tersebut akan menjadi motivasi kuat bagi para pengelola untuk melakukan pembinaan meskipun pola-pola yang dilakukan kemungkinannya berbeda dengan pola-pola yang dilakukan oleh para orang tua dirumah masing-masing..

Komunikasi dengan pihak orang tua menjadi kebutuhan yang sangat penting dalam proses pembinaan disetiap satuan pendidikan, karena pada dasarnya orang tualah yang sebenarnya memiliki pengaruh yang sangat kuat dalam pembentukan karakter siswa. Lingkungan pertama yang berhubungan dengan anak dalam proses perkembangan kepribadiannya menurut Soerjono Soekanto (1999:495) adalah orang tuanya, saudara-saudaranya yang lebih tua (kalau ada), bahkan mungkin kerabat dekat yang tinggal serumah atau bahkan termasuk pembantu rumah tangganya. Melalui lingkungan keluarga itulah seseorang mengalami proses sosialisasi awal yang menjadi modal dasar dalam proses sosialisasi selanjutnya.

(8) Mahkamah Akhlak.

Mahkamah akhlak adalah tim yang terdiri dari unsur-unsur pimpinan pondok, yang bertugas secara khusus untuk membahas dan mencarikan solusi serta menetapkan kebijakan, terkait dengan pelanggaran berat terhadap tata tertib, maupun pelanggaran berulang-ulang yang dilakukan oleh santri, setelah melalui proses pembinaan dan penanganan secara bertingkat dari bawah sesuai dengan prosedur yang telah ditetapkan dalam institusi pondok.

\section{Sikap Santri Terhadap Penerapan \\ Pola Sosialisasi Represipatif}

Penerapan pola sosialiasi represipatif (Repressivatife Socialization) di pesantren IMMIM disikapi atau ditanggapi dan diterima oleh santri dengan sikap positif. Munculnya sikap santri yang positif, karena pola sosialisasi represipatif ini mengarahkan santri pada terbangunnya keseimbangan antara penegakan kedisiplinan dengan pemberian kebebasan dalam batas-batas tertentu. Keseimbangan antara kebebasan dan penegakan disiplin secara sinergis merupakan salah satu factor terbentuknya karakter atau kepribadian yang stabil. Soerjono Soekanto (1990: 495) menjelaskan hal ini bahwa dalam membentuk kepribadian dan karakter seseorang menjadi stabil, maka aspek mendasar yang harus ditanamkan adalah memberikan pengetahuan dasar-dasar pola pergaulan melalui penanaman disiplin dan kebebasan secara serasi.

Selain itu pola sosialisasi represiapatif ini juga memberikan ruang kepada santri untuk ikut terlibat dalam proses-proses penerapan kebijakan, khususnya penerapan berbagai norma-norma, nilai-nilai dan berbagai aturan lain di dalam pondok. Sehingga, secara afeksi santri merasa mendapatkan penghargaan dan perlakukan yang pantas dan wajar, kemudian memotivasi santri untuk lebih memahami dan memaknai tujuan-tujuan berbagai normanorma, aturan yang berlaku. Seiring dengan itu secara kognisi dipihak pengelola pondok menindak lanjuti dengan proses pengenalan berbagai aturan, norma-norma pembinaan yang diterapkan, baik melalui pemasangan tata tertib diberbagai tempat, maupun dalam bentuk pengarahan umum di mesjid, diasrama masingmasing oleh para wali thalib, dikelas oleh para guru, termasuk dalam upacara bendera.

Dengan afeksi (perasaan) dan kognisi (pengetahuan) positif santri mengenai tujuantujuan dan makna-makna berbagai normanorma, aturan-aturan yang diterapkan, mendorong santri untuk selalu berusaha menyesuaikan keinginan-keinginan pribadinya dengan tuntutan pola hidup bersama di dalam pesantren. Sehingga meskipun berbagai aturanaturan dan norma-norma pondok cukup ketat dan berat untuk dijalani, tetapi santri menyikapi dengan positif dan menganggap sebagai suatu keharusan yang wajar di berlakukan. Kondisi tersebut sangat mendukung berjalannya prosesproses pembinaan dengan baik, sehingga santri lebih mudah diarahkan kepada tujuan-tujuan pembinaan.

Dalam teori-teori social, khususnya teori "konsistensi afektif-kognitif" menunjukkan adanya relevansi yang kuat. karena dalam teori yang dikembangkan oleh Rosenberg ini, berasumsi bahwa terdapat konsistensi hubungan yang kuat antara komponen afeksi dengan 
komponen kognisi dalam menyikapi suatu fakta atau keadaan. Artinya bahwa di dalam memahami dan menyikapi suatu fakta atau keadaan, seseorang selalu berusaha untuk membuat kesesuaian antara afeksinya dengan kognisinya secara konsisten. Sehingga dapat dikatakan bahwa sejauh mana aspek afeksi seseorang terhadap suatu keadaan atau fakta akan sangat mempengaruhi aspek keayakinan, pendirian dan juga pengetahuannya terhadap fakta atau keadaan tersebut. Dengan demikian untuk mengubah suatu sikap menurut pandangan teori ini, maka aspek mendasar yang harus dicermati terlebih dahulu adalah aspek atau komponen afeksi, kemudian akan mempengaruhi perubahan komponen kognisi lalu akan diikuti oleh perubahan sikap. (Internet: 2015, digilib.unismus.oc.id)

$\begin{array}{cc}\text { Dalam kajian hasil } & \begin{array}{r}\text { penelitian } \\ \text { diuraikan }\end{array}\end{array}$
menunjukkan bahwa santri IMMIM mampu menjalani proses pembinaan dengan berbagai macam norma-norma dan aturan-aturan yang ketat, sangat erat kaitannya dengan penggunaan pola sosialisasi represipatif (Repressivatife Socialization) dimana dalam proses pola sosialisasi represipatif ini mengarahkan santri agar mampu membangun keseimbangan antara aspek komponen afeksinya dengan komponen kognisinya. Sehingga sangat mendukung terjadinya perubahan sikap santri kearah yang lebih positif .

\section{Dampak Penerapan Pola Sosialisasi \\ Represipatif di Pesantren IMMIM}

Dampak penerapan pola sosialisasi represipatif yang dimaksudkan dalam pembahasan ini, adalah sejauh mana pola sosialisasi represipatif ini mempengaruhi tindakan santri dalam upaya pembentukan karakter yang unggul, yaitu karakter yang dimotori oleh pengamalan nilai-nilai islami dalam tindakan santri.

Pola sosialisasi represipatif merupakan pola sosialisasi yang berupaya menanamkan persepsi positif dalam diri santri terhadap tatanan norma pondok. Sehingga santri akan memahami dan dapat menerima berbagai ketentuan pondok secara sadar, misalnya mengenai perlu dan pentingnya keseimbangan antara penegakan kedisiplinan disatu sisi dengan pemberian kebebasan disisi lain dalam menjalani berbagai aturan, ketentuan-ketentuan, yang harus ditegakkan dalam kehidupan bersama di dalam pondok.
Hasil penelitian yang dilakukan di Pesantren IMMIM menunjukkan bahwa dengan penerapan pola sosialisasi represipatif sangat mendorong terbangunnya persepsi positif santri terhadap berbagai peraturan dalam proses pembinaan. Sehingga memberikan rasa nyaman pada santri dalam melakukan aktivitas dan berinteraksi dengan lingkungan sosialnya sebab dengan pola ini santri memahami batasanbatasan tindakan yang bisa atau tidak bisa berdasarkan kesadaran sendiri, yang kemudian berdampak sangat positif khususnya pada aspek aspek sebagaimana diuraikan berikut ini:

\section{1). Dampak Pada Pondok Pesantren}

\section{(a). Aspek proses pembinaan.}

Secara penomenologis dengan keteraturan aktivitas dikalangan santri dalam menjalani pola-pola kehidupan di dalam pondok, menjadi salah satu indikator bahwa proses pembinaan berjalan dengan baik. Hal ini kemudian berdampak positif terhadap terbangunnnya solidaritas dalam bentuk komunikasi yang efektif dikalangan santri, baik di dalam proses pembelajaran di kelas oleh guru, maupun dalam kehidupan santri di asrama, dimesjid, diruang makan dan diberbagai tempat di dalam pondok semakin menunjukkan adanya perbaikan yang positif.

\section{(b).Aspek HAM.}

Pola sosialisasi represipatif dapat meminimalisasi terjadinya pelanggaran HAM oleh para pembina, guru dan para pengelola pondok oleh karena sanksi-sanksi yang diberlakukan, baik sanksi yang sifatnya sanksi fisik maupun non fisik, adalah merupakan hasil kesepakatan dan persetujuan dengan santri. Selain itu proses yang dilakukan didalamnya telah dipahami sebelumnya oleh semua santri sebagai sasaran pembinaan, sehingga ketika terjadi pelanggran terhadap aturan-atruran pondok oleh santri, pada dasarnya para santri sudah paham dan mengerti sanksi yang akan diberikan, sehingga pemberlakuan sanksi diterima oleh santri sebagai suatu keharusan yang wajar, dan mengurangi tingkat protes dan konflain.

\section{(c). Aspek eksistensi pesantren}

Secara kelembagaan, pondok pesantren IMMIM tetap dapat eksis bertahan dan berkembang dengan baik ditengah-tengah pergumulan peradaban masyarakat yang semakin modern dengan segala macam 
tuntutan dan implikasi dampak negative positifnya. Eksistensi tersebut dapat dipertahankan oleh karena tumbuhnya kepercayaan dari masyarakat, terutama khsusunya para orang tua santri untuk menitipkan anaknya dibina dan dididik di pesantren. Tumbuhnya kepercayaan ini terlihat atau ditandai dengan jumlah peminat yang mondok tetap stabil dan mengalami kenaikan. Terutama pada dua tahun terkahir dilakukan pembatasan jumlah santri yang dapat diakomodir untuk diterima oleh karena factor kesesuaian daya tampung baik untuk ruang belajar di kelas, maupun asrama untuk pemondokan santri. (Data perkembangan jumlah santri, tahun 20152017)

\section{2). Dampak Pada Santri}

Pola sosialisasi represipatif ini, menjadi pendorong yang kuat terbangunnya sikap dan karakter santri yang tidak saja baik tetapi juga unggul, dalam artian bahwa karakter yang terbangun adalah karakter yang dilandasi oleh nilai-nilai ajaran agama (Islam), dan terbangun berdasarkan kesadaran dari santri sendiri.

Karakter seringkali dimaknai sebagai suatu sikap konsekwen tidaknya dan konsisten atau teguh tidaknya seseorang dalam memegang pendapat dan pendirian yang dianggap benar sesuai dengan tatanan etika yang menjadi nilai dan norma social dimana seseorang itu berada. Thomas Lickona (2016:82-83). Sedangkan pendidikan karakter sering diartikan sebagai upaya untuk menanamkan nilai-nilai yang benar, budi pekerti, moralitas, watak dan lain sebagainya yang berhubungan dengan sikap dan tindakan-tindakan baik. Selain itu juga pendidikan karakter diarahkan pada upaya membantu peserta didik untuk memahami mengapa harus berbuat baik. mengapa perlu melakukan hal-hal baik. Jadi tidak hanya mengerti tentang adanya sesuatu yang baik, benar dan pantas, tetapi juga memahami alasannya. (Abdullah Sani, 2016:26).

Dalam kaitan tersebut proses sosialisasi yang sesuai dan bersinergis dengan upaya pendidikan karakter adalah pola sosialisasi represipatif, oleh karena dalam pola ini memadukan antara tuntutan ketaatan dan pemberian kebebesan, sehingga harus mengedepankan pemahaman tentang berbagai pertanyaan mengapa tidak boleh terlalu ketat dan tidak boleh terlalu bebas, maka akan terbangun keseimbangan dalam tindakan perilaku yang diharapkan. Wujudnya dalam dalam bentuk kemampuan santri berupa:

(1). Penyesuaian diri.

Penyesuaian diri secara singkat dapat dimaknai adalah proses bagaimana individu dapat mencapai keseimbangan diri untuk memenuhi kebutuhan sesuai dengan tuntutan lingkungan, baik lingkungan manusia disekitarnya, lingkungan budaya, ekonomi dan maupun lingkungan geografis.

Penyesuaian diri yang baik akan benarbenar dapat dicapai jika seseorang tersebut terhindar dari tekanan, goncangan dan ketegangan jiwa, oleh karena itu penyesuaian diri setidaknya melibatkan tiga unsur utama menurut Schniders (dalam Ali \&Asrori, 2012: 181 yaitu: (a). Motivasi, (b). Sikap terhadap realitas, dan (c).Pola dasar penyesuaian diri itu sendiri.

Salah satu dampak penerapan pola sosialisasi represipatif adalah terbangunnya kemampuan penyesuaian diri pada santri dalam aktivitas kesehariannya, hal ini sesuai dengan hasil pengamatan baik secara fenomenologis terhadap tindakan santri maupun berdasarkan hasil wawancara yang dilakukan dalam penelitian ini yang menunjukkan bahwa santri IMMIM cukup mampu menyesuaikan diri dengan tuntutan hidup bersama dalam lingkungan pesantren.

(2). Percaya diri

Percaya diri dapat dimaknai sebagai suatu keadaan kejiwaan seseorang yang memiliki konsep komitmen terhadap apa yang diyakini benar, biasanya berwujud dalam bentuk sikap keberanian mengutarakan, memperkenalkan, melakukan dalam bentuk bertindak dan berperilaku. Percaya diri berbeda dengan sikap sombong dan angkuh, sebab sikap sombong dan angkuh didalamnya terdapat perasaan menyepelekan bahkan memandang rendah hal-hal yang ada diluar selain dirinya (manusia, alam bahkan takdir dll). Sehingga berkecenderungan susah menerima nilai kebenaran. Sedangkan percaya diri lebih menekankan pada adanya komitmen terhadap apa yang diyakini benar, patut dan pantas sesuai dengan nilai dan norma yang berlaku tanpa ada tendensi merendahkan hal-hal apa yang ada diluar dirinya. Sehingga sangat elastis dalam menerima suatu nilai-nilai kebenaran. Sikap yang elastis dalam mempertimbangkan dan menerima kebenaran yang ada sebagai informasi 
yang datang diluar diri merupakan aspek mendasar dalam peningkatan kecerdasan wawasan dan pengetahuan yang luas.

Salah satu aspek mendasar dalam temuan penelitian ini adalah bahwa pola sosialisasi represipatif yang diterapkan di pesantren IMMIM mendorong terbangunnya rasa percaya diri santri terhadap apa yang diyakini benar sesuai dengan nilai-nilai dan norma-norma pondok. Rasa percaya diri santri tersebut mendorong munculnya kecerdasan santri berwujud dalam bentuk keberanian berkreativitas baik dibidang akademik, seni, olah raga maupun bidang-bidang lain.

(3). Tanggung jawab.

Menumbuhkan sikap bertanggung jawab peserta didik dalam kerangka pembinaan karakter, adalah salah satu hal mendasar yang sangat penting dilakukan, oleh karena dengan kemampuan bertanggung jawab akan mendorong tumbuhnya karakter santri yang mandiri. Tanggung jawab dapat dikatakan suatu kesadaran manusia akan tingkah laku atau perbuatannya. Dapat juga diartikan berbuat sesuatu sebagai perwujudan kesadaran akan kewajibannya. Mukti Ali, dkk (2017:183)

Tanggung jawab akan muncul jika dalam diri seseorang tersebut memiliki motivasi yang kemudian akan mendorong tumbuhnya sikap disiplin dan empati. Motivasi yang dimaksudkan adalah adanya dorongan yang lahir dari kesadaran akan sesuatu yang harus dilakukan dengan baik. Sedangkan disiplin berarti seseorang menunjukkan perilaku taat, patuh pada aturan yang ada dalam menjalankan tanggung jawab tersebut. dan empati berarti seseorang tersebut memiliki rasa kepedulian kepada orang lain sehingga dalam berbuat baik kepada orang lain tidak dirasakan sebagai beban. Zubaedi (2011:40).

Nilai rasa tanggung jawab sangat penting tertanam kuat dalam diri peserta didik karena dengan rasa tanggung jawab ini merupakan pondasi yang sangat penting bagi tumbuh kembangnya budaya moralitas disuatu satuan pendidikan. Budaya moralitas di sekolah adalah terbangunnya kemauan untuk selalu berbuat baik dikalangan peserta didik dan pengelola satuan pendidikan menjadi kebiasaan yang melembaga pada satuan pendidikan. ( Thomas Lickona, 2016:453-454).

Beberapa budaya moral yang dapat berkembang melalui tanggung jawab yang melembaga dalam satuan pendidikan antara lain terbangunnya (a). Sikap amanah, (b). Sikap peduli (c). Sikap sportifitas, (d). ketaqwaan,(e). sikap adil. dan (f). sikap disiplin. Serta (g). sikap mandiri. (Abdullah Sani 2016: 34).

Dalam kehidupan santri di pesantren khususnya di pesantren IMMIM, nilai rasa tanggung jawab menjadi hal yang mutlak dimiliki oleh para santri, oleh karena untuk mengurusi keperluan sehari-hari santri seperti mempersiapkan diri mengikuti berbagai kegiatan pondok, semuanya dibebankan kepada santri secara mandiri, seperti mencuci pakaian sendiri, mempersiapkan tempat tidur, melipat dan perapikan pakaian kedalam lemari, dan lainlain, semua itu dimaksudkan untuk menanamkan nilai tanggung jawab yang kemudian nantinya akan berimbas pada terbangunnya nilai kemandirian santri.

Sekaitan dengan upaya menumbuhkan nilai tanggung jawab dalam satuan pendidikan terutama pendidikan berbasi pesantren, maka sangat diperlukan sinergitas antara komponen peserta didik, guru serta para pembina, dan orang tua. Peserta didik bertanggung jawab melakukan aktivitas yang menjadi tugas yang diberikan kepadanya, Guru memberikan pemahaman tentang tanggung jawab serta menjadi teladan yang baik dalam penerapan kebiasaan bertanggung jawab, serta orang tua memberikan perhatian yang maksimal. Dengan demikian akan terbangun budaya moralitas sebagai karakter yang diharapkan dimiliki oleh santri,Mukti Ali, dkk (2017:188)

\section{(4). Kesetaraan atau Universalisme}

Salah satu aspek sosialisasi yang sangat penting dikembangkan disatuan pendidikan untuk membekali peserta didik dengan karakter yang baik, adalah menanamkan pemahaman kepada peserta didik tentang perlunya mengedepankan cara pandang bahwa manusia di dunia memiliki kesamaan dan kesetaraan. Kesetaraan yang dimaksud bukanlah berarti memperlakukan setiap orang secara sama, namun lebih pada bagaimana mengakui bahwa manusia pada dasarnya memiliki hak dan kewajiban yang harus dihormati dan dihargai dengan prinsip tidak diskriminatif.(Mukti Ali dkk, 2017: 111). Dengan pemahaman ini akan mendorong munculnya prinsip universalisme. Universalisme itu sendiri dapat diartikan antara lain adanya perlakuan yang sama antara satu dengan yang lainnya. tanpa memandang perbedaan latar belakang status social. Damsar (Online: http://books.google.co.id). Prinsip kesetaraan dan universalisme merupakan sebagai standar yang akan dapat menciptakan 
kestabilan dalam hubungan antar manusia, sebab dengan prinsip ini manusia akan selalu memiliki keinginan untuk menghormati dan menghargai keberadaan orang lain meskipun berbeda dengan dirinya.

Al-Qur'an sebagai petunjuk hidup masyarakat Islam baik secara individual maupun sebagai suatu komunitas, kelompok, telah menjelaskan kesetaraan ataupun universalisme ini, didalam surah Al-Hujurat: 13. Yang artinya "Wahai manusia, Kami ciptakan kalian laki-laki dan perempuan, dan Kami jadikan kalian bersuku-suku dan berbangsa-bangsa, agar kalian saling mengenal, Sesungguhnya orang yang paling mulia disisi Allah adalah yang paling bertaqwa; (QS. Al-Hujurat: 13)

Dari beberapa pengertian diatas dapat dipahami bahwa kesetaraan dan universalisme dalam satuan pendidikan adalah memperlakukan peserta didik tanpa membedakan antara satu dengan yang lainnya (kecuali karena kondisi atau keadaan tertentu peserta didik) sehingga akan mendorong juga terbangunnya rasa kesamaan hak dan kewajiban diantara para peserta didik tanpa memandang adanya perbedaan dan dikhotomi peserta didik karena latar belakang social.

Merujuk pada hasil penelitian yang dilakukan di pesantren IMMIM, menunjukkan bahwa melalui penerapan pola sosialisasi represipatif mendorong tertanamanya cara pandang kesetaraan dan universal dikalangan santri dengan baik. dan hal tersebut berdampak signifikan secara positif terhadap (1). Terbangunnya rasa kesetia kawanan sesama santri. (2). Sikap solidaritas santri yang cukup tinggi terhadap sesama teman, misalnya saling kepedulian ketika ada yang sakit, kiriman makanan dari orang tua dianggap sebagai milik bersama dan dinikmati bersama, bahkan bajupun seringkali menjadi milik bersama. (3). Imbas dari sikap solidaritas tersebut adalah bahwa santri yang berasal dari berbagai latar belakang budaya, kebiasaan dan tradisi yang berbedabeda karena perbedaan daerah masing-masing, mampu menciptakan kehidupan bersama yang baik dan bersinergis antara satu dengan yang lainnya sebagai masyarakat atau komunitas santri.

\section{3). Dampaknya kepada masyarakat khusunya Orang Tua Santri}

Pola sosialisasi represipatif yang potensial dapat mendorong terbangunnya karakter unggul dikalangan santri, memberi dampak positif juga kepada para orang tua santri, bahkan kepada masyarakat umum. sebab dengan karakter santri yang unggul merupakan modal dasar yang utama bagi santri untuk hidup secara baik dan layak ditengah-tengah masyarakat. Dengan demikian penerapan pola sosialisasi represipatif dalam proses pembinaan santri memberi dampak posisitif terhadap orangtua santri bahkan masyarakat secara umum, antara lain dalam bentuk berupa: (a). Adanya sikap optimis orang tua bahwa anaknya memiliki pondasi karakter yang baik sebagai modal dasar agar dapat memposisikan diri secara benar dalam melakukan interaksi dan pergaulan ditengah-tengah masyarakat. (b). Meminimalisasi rasa cemas para orang tua santri terhadap kemungkinan anaknya tumbuh menjadi manusia yang berperilaku tidak sesuai dengan berbagai macam nilai dan norma-norma masyarakat, tertutama nilai dan norma-norma agama (Islam). (c). Penerapan pola sosialisasi represipatif di pondok pesantren, pada dasanya telah membantu para orang tua santri untuk mendidik dan membimbing anak yang merupakan kewajiban orang tua, menjadikan mereka menjadi orang-orang yang beriman, taat dan saleh saleha kepada Allah Swt.

\section{SIMPULAN DAN SARAN}

Berdasarkan pada pengungkapan faktafakta yang diperoleh dari berbagai informen di lapangan, setelah melalui analisis dan pembahasan maka peneliti dapat menarik beberapa kesimpulan yang merupakan hasil dari penelitian ini sebagai berikut:

1. Implementasi penerapan pola sosialisasi represipatif (Repressifative Socialization) di Pessantren IMMIM Putra Makassar dilakukan dengan cara sebagai berikut: (a). Pemberdayaan fungsi pengelola secara structural yaitu pola tersebut dilaksanakan melalui kerja tim. dimana semua bagian-bagian dalam struktur pengelolaan pesantren berkewajiban bekerja sama sebagai tim work dalam menjalankan proses sosialisasi ini sesuai pembagian tugas dan kewenangan masing-masing dalam struktur. (b). Mekanisme pola implementasi dilakukan 
dengan cara (1) Membangun kemampuan adaptasi diri melalui memberikan pemahaman pengelola terkait konsep dasar pola sosialisasi represipatif, demikian juga memberikan pemahaman dan pengetahuan terhadap santri terkait program-program pembinaan.dengan tujuan agar pemahaman tersebut menjadi motivasi untuk melakukan upaya penyesuaian diri. (2). Adanya keterlibatan santri dalam menetapkan kebijakan, (3) Komunikasi terarah pada tujuan yang ingin dicapai, (4) Memberlakukan imbalan dan sanksi baik secara material maupun simbolik,

Melakukan proses sosialisasi seimbang, (6) Adanya pembatasan keperluan santri sesuai kebutuhan, (7) Dilakukan pantauan sikap santri dalam segala aspek disemua tmpat, (8) Mengepektifkan komunikasi dengan orang tua/walisantri, (9) Mahkamah akhlak bagi santri yang terdeteksi selalu melanggar aturan-aturan pondok.

2. Penerapan pola sosialisasi represipatif (Repressifative Socialization) di Pesantren IMMIM Putra Makassar, disikapi atau ditanggapi secara positif oleh santri, yang terlihat dalam tindakan-tindakan yang dilakukan oleh santri menunjukkan sikap pro aktif dalam proses pembinaan yang dilakukan, sehingga santri merasa tidak terbebani dan tertekan dengan peraturan-peraturan yang ditetapkan dan sanksi-sanksi yang mengiringi dalam prosesproses pembinaan. Bahkan dengan pola sosialisasi represipatif ini santri merasa terbangun kesadaran sendiri untuk mendukung dan mengikuti program pembinaan secara maksimal..

3. Dampak penerapan pola sosialisasi represipatif di pesantren IMMIM sebagai lokus penelitian ini, menunjukkan pengaruh yang sangat positif antara lain, (a). Pada aspek proses pembinaan, yaitu terbangunnya sikap santri yang positif, dan mendorong para santri untuk selalu berusaha menyesuaikan keinginankeinginan pribadinya dengan tuntutan-tuntutan norma-norma, nilai-nilai dan berbagai aturan yang diberlakukan dalam mekanisme proses pembinaan sehingga berdampak positif pada berjalannya proses pembinaan dengan baik, yang terlihat di dalam proses pembelajaran di kelas oleh guru, maupun dalam kehidupan santri di asrama, dimesjid, dan lain-lain tempat di dalam pondok. (b). Pendidikan karakter kepribadian santri, yaitu (1). Tumbuhnya kemampuan penyesuaian diri, (2). Terbangunnya rasa percaya diri, (3) Tumbuhnya rasa tanggung jawab, yang mendorong munculnya sikap, amanah, sikap peduli, sportifitas, ketaqwaaan, sikap adil, sikap disiplin.dan sikap kemandirian. (c). Universalisme, yaitu bahwa dalam satuan pendidikan peserta didik diperlakukan secara adil tanpa membedakan latar belakang social antara satu dengan yang lainnya (kecuali karena kondisi atau keadaan tertentu peserta didik) sehingga akan mendorong juga terbangunnya dalam diri peserta didik perasaan bahwa mereka memiliki kesamaan hak dan kewajiban diantara para peserta didik yang lain tanpa memandang adanya perbedaan dan dikhotomi karena latar belakang social.

Dengan demikian berdampak signifikan secara positif terhadap (1). Terbangunnya rasa kesetia kawanan diantara santri. (2). Sikap solidaritas santri yang cukup tinggi terhadap sesama teman, (3). Imbas dari sikap solidaritas tersebut adalah bahwa santri yang berasal dari berbagai latar belakang budaya, kebiasaan dan tradisi yang berbeda-beda karena perbedaan daerah masing-masing, mampu menciptakan kehidupan bersama yang baik dan bersinergis antara satu dengan yang lainnya sebagai masyarakat atau komunitas santri.

Mengacu pada beberapa kesimpulan hasil penelitian yang peneliti uraikan diatas, maka peneliti mengajukan beberapa saran sebagai berikut:

1. Kepada pengelola pondok Pesantren IMMIM Putra Makassar, agar senantiasa melakukan evaluasi terhadap proses penerapan pola sosialisasi represipatif (Repressifative Socialization) ini, agar tetap dapat disesuaikan dengan tuntutan perkembangan aspek kejiwaan santri. Sehingga pola sosialisasi represipatif ini tetap dapat bersinergis dengan karakter pendidikan berbasis pesantren.

2. Kepada para pengelola satuan pendidikan baik yang berbasis pesantren maupun yang berbasis sekolah umum, yang selama ini cenderung menggunakan hanya salah satu pola sosialisasi saja misalnya hanya dengan pola sosialisasi represif atau partisipatif, sebaiknya mencoba pola sosialisasi represipatif. Demikian juga dalam pembinaan anak-anak di rumah dalam keluarga masing-masing.

3. Kepada para Guru, pembina/pengelola satuan pendidikan , hendaknya selalu mendekati peserta didik dengan cara-cara humanis yang dapat membuat peserta didik merasa dihargai, diperhatikan, dan dibutuhkan. Sehingga para peserta didik tersebut termotivasi menunjukkan 
sikap positif yang lebih pro aktif dalam proses pembinaan yang dilakukan. Salah satu yang ditawarkan adalah dengan menerapkan pola sosialisasi represipatif (Repressifative Socialization) dalam proses pembinaan, pengajaran dan lain-lain proses pembimbingan.

4. Kepada para peneliti yang berminat pada masalah proses pembinaan pada satuan pendidikan, diharapkan untuk dapat melanjutkan penelitian ini, sehingga hasilnya nanti jauh lebih detail dan maksimal.

\section{DAFTAR RUJUKAN}

Ali Mukti dkk. 2017. Pendidikan Karakter Berbasis Pesantren; Jakarta Selatan: Rumah Kitab.

Departemen Agama RI, 2009. Al-Qur'an Tajwid Dan Terjemah; Bandung:Jabal Raudhatul Jannah.

Idi Abdullah. H, 2016. Sosiologi PendidikanIndividu, Masyarakat, dan Pendidikan ; jakarta : PT. Raja Grafindo.

Lickona Thomas, 2016. Educating for Character. Mendidik untuk membentuk karakter; Jakarta: Bumi Aksara..

Mohammad Ali dan Mohammad Asrori, 2012. Psikologi Remaja Perkembangan Peserta Didik. Jakarta: PT. Bumi Aksara

Moleong, J.Lexy. 2007. Metodologi Penelitian Kualitatif. Bandung:Rosdakarya

Sugiyono, 2016. Metode Penelitian Pendidikan Pendekatan Kuantitatif, Kualitatif, dan $R \& D$; Bandung: Alfabeta

Sani Ridwan Abdullah, Kadri Muhammad, 2016. Pendidikan Karakter Mengembangkan Karakter Anak Yang Islami; Jakarta : Bumi Aksara.

Soekanto Soerjono, 1999. Sosiologi Suatu Pengantar; Jakarta : Rajawali Pers

Undang Undang Republik Indonesia No. 20 Tahun 2003, tentang Sistem Pendidikan Nasional
Zubaedi, 2011. Desain Pendidikan Karakter Konsepsi Dan Aplikasinya Dalam Lembaga Pendidikan; Jakarta: Kencana

Damsar.,.......Pengantar Sosiologi Pendidikan (Online: $\quad$ http://books.google.co.id). Diakses 08 Maret 2018).

Hermanto Bambang. 2014. Makna Sosialisasi Nilai Orang Tua Terhadap Anak Tunggal, (online), (Journal. Unair.ac.id. Diakses 30 November 2017)

Muliyono Dafi. dkk, 2014. Fungsi Sosialisasi Represif terhadap Perilaku Disiplin Siswa di SMA Islam Bawai Pontianak, (online), (journal, untan.ac.id. Diakses 30 November 2017)

Rikafatmawati,2015.Teori Keseimbangan,(online), (rikafatmawati.blogpost.co.id) Diakses 08 Januari 2018)

2015. Teori Konsistensi AfektifKognitif, (online), (digilib.unismus.oc.id) Diakses 08 Januari 2015) 